\title{
Upaya Meningkatkan Pemahaman Eksplorasi Karir Melalui Layanan Bimbingan Kelompok dengan Teknik Diskusi Kelompok
}

\author{
Tovik Priyatno \\ MA Unggulan Cokroaminoto Banjarnegara \\ J1.Tentara Pelajar, Kel. Sukonandi, Banjarnegara, Jawa Tengah, Indonesia \\ Email: tovik_vic@yahoo.com
}

\begin{abstract}
This study aims to determine the understanding improvement of career exploration through group guidance services with a group discussion technique. This study uses classroom action research conducted in two cycles. The research subjects are eight students of grade IX E SMP Muhammadiyah 7 Yogyakarta, taken by using purposive sampling. Data collection instruments use understanding questionnaires of career exploration and observation guidelines. An understanding of the students' career exploration before and after group guidance services group by group discussion techniques were analyzed using t-test formula. Results of data analysis obtained by value $t=7.812>t$ table (1.895), with the results mean score of 119.87 pretest and posttest mean score increased to 155.75 . The results of this study concluded there is an understanding improvement of career exploration through group guidance services with the student a group discussion technique. The results of this study can be used as information for guidance and counseling teachers in an effort to improve the understanding of students' career exploration through group guidance services by utilizing the technique of a group discussion.
\end{abstract}

Keywords: career exploration, group guidance, group discussion

\begin{abstract}
Penelitian ini bertujuan untuk mengetahui peningkatan pemahaman eksplorasi karir melalui layanan bimbingan kelompok dengan teknik diskusi kelompok. Penelitian ini menggunakan metode penelitian tindakan kelas yang dilaksanakan dalam dua siklus. Subjek penelitian berjumlah delapan siswa kelas IX E SMP Muhammadiyah 7 Yogyakarta, yang diambil menggunakan purposive sampling. Instrumen pengumpulan data menggunakan angket pemahaman eksplorasi karir dan pedoman observasi. Pemahaman eksplorasi karir siswa dari sebelum dan sesudah diberikan layanan bimbingan kelompok dengan teknik diskusi kelompok dianalisis menggunakan rumus $t$-tets. Hasil analisis data diperoleh nilai t hitung $=7,812>$ t table (1,895), dengan hasil rerata skor pretest 119,87 dan rerata skor posttest meningkat menjadi 155,75. Hasil penelitian ini menunjukkan bahwa ada peningkatan pemahaman eksplorasi karir melalui layanan bimbingan kelompok dengan teknik diskusi kelompok pada siswa. Hasil penelitian ini dapat dijadikan sebagai informasi bagi guru bimbingan dan konseling dalam upaya meningkatkan pemahaman eksplorasi karir siswa melalui layanan bimbingan kelompok dengan memanfaatkan teknik diskusi kelompok.
\end{abstract}

Kata kunci: eksplorasi karir, bimbingan kelompok, diskusi kelompok

\section{Pendahuluan}

Era Globalisasi menuntut kualitas kemampuan yang dimiliki seseorang agar dapat bersaing dalam kancah global. Sumber daya manusia harus dikembangkan untuk menjadi sarana pembangunan sebagai pemikiran, rencana, penggerak, dan pelaksana. Pendidikan nasional bertujuan untuk mengembangkan manusia Indonesia yang berkualitas. Pendidikan merupakan awal untuk dapat menentukan karir seseorang. Generasi muda sebagai penerus bangsa yang sedang menjalani proses belajar di institusi pendidikan hendaknya dibekali persiapan diri untuk memasuki dunia kerja. Bekal yang harus dimiliki oleh generasi muda bukan hanya bekal sebagai tenaga kerja yang mampu kerja, akan tetapi tenaga kerja yang bisa mengeksplorasi diri dalam bekerja dan berguna bagi kemaslahatan hidup manusia. Pemahaman eksplorasi karir perlu ditanamkan pada individu sejak di bangku sekolah.

Setiap siswa harus mampu mengambil keputusan dalam memegang suatu jabatan yang akan di jalani untuk masa depan, berdasarkan pemahaman tentang diri sendiri dan situasi hidup serta berpedoman pada pengolahan informasi yang releven tentang lingkungan hidup siswa. Kemampuan tersebut harus dipupuk sejak dini supaya siswa semakin paham akan kemampuan diri sendiri, lingkungan hidup, dan proses pengambilan keputusan, serta semakin mantap untuk mempersiapkan diri dalam hal pengetahuan, ketrampilan, sikap serta nilai, yang 


\section{PRIYATNO}

semuanya diperlukan dalam menekuni karir siswa.

Pengangguran yang semakin tinggi di Indonesia sebagian besar adalah kaum remaja, baik itu remaja awal, remaja pertengahan, maupun akhir (Hidayat, 2012). Pengangguran tersebut diakibatkan pengetahuan informasi karir yang rendah dan tidak mempunyai bekal untuk memasuki dunia kerja. Informasi karir yang dimaksud yaitu segala aktivitas yang berkaitan dari jenjang pendidikan yang sesuai bakat minat siswa sampai dengan pekerjaan. Oleh karena itu informasi karir dan beberapa keterampilan sebagai persiapan perencanaan karir sangat diperlukan bagi remaja awal atau usia SMP.

Berdasarkan hasil wawancara peneliti dengan kepala SMP Muhammadiyah 7 Yogyakarta pada tanggal 12 September 2013, diperoleh data bahwa siswa kelas VIII E sebaiknya sudah mendapatkan informasi karir karena masih terdapat siswa yang bingung dan ragu-ragu dalam memilih kelanjutan karir. Hasil analisis yang digunakan untuk mengidentifikasi permasalahan siswa di SMP Muhammadiyah 2 Yogyakarta dengan Daftar Cek Masalah (DCM). Hasil analisis tugas perkembangan menunjukan pada topik masalah masa depan jabatan dengan persentase $80 \%$.

Bagi remaja awal, pendidikan sekolah sangat penting dan akan bermakna pada diri sendiri dan masyarakat. Persiapan sebelum menghadapi dunia kerja adalah pendidikan dari sekolah dasar hingga ke perguruan tinggi, lalu sampai tahap ke masa dunia kerja yang penuh persaingan. Oleh karena itu, remaja awal harus bisa memilih bidang yang sesuai dengan kemampuan diri sesuai minat dan bakat yang dimiliki.

Pemahaman eksplorasi karir sangat penting bagi remaja awal supaya mampu memilih dan mendapat informasi yang tepat dan mampu mengaplikasikan minat dan bakat siswa sesuai dengan yang dimiliki. Eksplorasi karir sangat diperlukan siswa agar dapat mengambil keputusan dan merencanakan karir. Kenyataan yang ada di sekolah, hampir sebagian besar siswa yang mempunyai minat terhadap salah satu jenis pekerjaan, tidak diimbangi dengan pengetahuan dan keterampilan baik yang bersifat akademik maupun sesuai minat dan bakat yang dimiliki untuk menunjang pekerjaan tersebut.
Pemanfaatan layanan bimbingan kelompok diharapkan mampu memberikan arahan bagi siswa yang masih mengalami kebingungan bahkan yang belum mempunyai gambaran tentang karir. Upaya untuk meningkatan pemahaman eksplorasi karir pada siswa tidak terlepas dari peran dan tanggung jawab beberapa pihak yaitu keluarga. salah satunya dalam lingkungan sekolah yaitu guru bimbingan dan konseling atau konselor. Eksplorasi karir merupakan cara untuk memperoleh informasi atau pilihan karir siswa tentang diri dan lingkungan sesuai bakat dan minat yang dimiliki individu dengan tujuan untuk membantu perkembangan karir siswa. Sebagai proses pencarian informasi atau pilihan, eksplorasi merupakan upaya untuk mencari informasi tentang karakteristik diri yang berkaitan dengan kelemahan dan kekuatan atau bakat dan minat individu untuk mencapai tujuan karir yang sesuai dengan bakat dan minat siswa.

Pada langkah ini eksplorasi karir sangat penting bagi remaja awal atau siswa SMP agar mampu memilih dan mendapat informasi yang tepat dan mampu mengaplikasikan bakat minat, sesuai dengan kemampuan yang dimiliki siswa di usia remaja awal atau memasuki tingkat SMP. Oleh karena itu eksplorasi karir sangat tepat di tanamkan sejak remaja awal atau SMP agar individu mampu memiliki informasi dan pilihan yang tepat itu memang penting agar siswa mampu menempatkan karakteristik atau kemampuan bakat dan minat ke jenjang pendidikan dan lebih siap menghadapi dunia kerja.

Tujuan penelitian ini untuk meningkatkan pemahaman eksplorasi karir melalui layanan bimbingan kelompok dengan teknik diskusi kelompok bagi siswa kelas IX E SMP Muhammadiyah 7 Yogyakarta. Pemahaman eksplorasi karir penting untuk ditingkatkan agar siswa mampu mencari, mendapatkan, dan mengelola berbagai macam informasi karir sehingga menjadi alternatif pilihan karir untuk dapat membantu siswa dalam memilih dan mempersiapkan diri dalam berkarir. Peningkatan pemahaman eksplorasi karir pada penelitian ini dispesifikkan melalui layanan bimbingan kelompok dengan teknik diskusi kelompok karena melalui teknik tersebut siswa dapat mengemukakan pendapat dan membicarakan topik-topik penting terkait dengan karir, mengembangkan nilai-nilai, dan mengembangkan 


\section{EKSPLORASI KARIR, BIMBINGAN KELOMPOK DENGAN TEKNIK DISKUSI KELOMPOK}

langkah-langkah secara bersama untuk menyelesaikan permasalahan yang dibahas dan didiskusikan dalam situasi kelompok. Hasil penelitian ini dapat dijadikan sebagai informasi bagi guru bimbingan dan konseling dalam upaya meningkatkan pemahaman eksplorasi karir siswa melalui layanan bimbingan kelompok dengan memanfaatkan teknik diskusi kelompok.

\section{Kajian Literatur}

\section{Eksplorasi Karir}

Sekolah menengah pertama merupakan salah satu jenjang karir awal bagi siswa. Pada proses menjalani jenjang karir ini siswa akan melewati tahap eksplorasi karir. Suherman (2011: 116) berpendapat bahwa eksplorasi karir didefinisikan sebagai keinginan individu untuk mengeksplorasi atau melakukan pencarian informasi terhadap sumber-sumber informasi karir. Menurut Sharf (dalam Suherman, 2010: 53) eksplorasi karir merupakan waktu ketika individu mengupayakan agar dirinya memiliki pemahaman yang lebih terutama tentang informasi pekerjaan, alternatifalternatif karir, pilihan karir, dan karir untuk mulai bekerja. Informasi karir diperoleh individu dari berbagai sumber misalnya guru bimbingan dan konseling, orang tua, orang yang sukses, teman, dll.

Eksplorasi karir merupakan kemampuan dan segala bentuk aktivitas individu dalam mencari, mendapatkan, dan mengelola berbagai macam informasi karir sehingga menjadi alternatif pilihan karir untuk dapat membantu individu dalam memilih dan mempersiapkan diri untuk karir siswa. Infomasi karir yang dimaksud adalah informasi-informasi yang berkaitan dengan suatu pekerjaan atau jabatan dan pendidikan, baik itu informasi umum seperti jenjang pendidikan yang mendukung maupun tentang lingkungan yang terkait dengan pekerjaan itu sendiri yang sesuai kemampuan yang dimiliki siswa. Maksud dari persiapan diri untuk suatu pekerjaan yaitu persiapan individu sebelum memasuki masa bekerja, tentu saja masa tersebut adalah saat individu sedang menempuh jenjang pendidikan ataupun melakukan pelatihan. Individu akan memiliki kemampuan untuk melakukan eksplorasi dengan baik ketika individu tersebut mempunyai, mengetahui, dan memahami petunjuk untuk melakukan sesuatu. Petunjuk tersebut yaitu indikator-indikator dari eksplorasi karir.

Menurut Suherman (2010: 117) indikatorindikator eksplorasi karir antara lain berusaha menggali dan mencari informasi karir dari berbagai sumber (guru bimbingan dan konseling, orang tua, orang yang sukses), memiliki pengetahuan tentang potensi diri (bakat, minat, intelegensi, kepribadian, nilai-nilai, dan prestasi), dan memiliki cukup banyak informasi karir. Indikator-indikator tersebut merupakan petunjuk terhadap kriteria bagi individu yang mampu melakukan eksplorasi karir secara efektif, positif dan dinamis.

Fungsi dari eksplorasi karir yaitu untuk mengetahui minat, bakat, kemampuan, kelebihan dan kekurangan, dan untuk merencanakan aktivitas-aktivitas yang mendukung karir individu agar mampu mempertimbangkan perencanaan karir sesuai dengan kebutuhan yang terkait dengan karir yang akan dipilih dimasa depan. Eksplorasi karir akan sangat berpengaruh bagi siswa sehingga perlu diperhatikan oleh guru bimbingan dan konseling, orangtua, dan semua pihak yang turut bertanggung jawab dalam perkembangan tahap eksplorasi karir pada siswa. Perhatian tersebut akan membawa dampak yang berbeda bagi setiap tahap eksplorasi karir pada siswa.

Faktor internal yang berpengaruh terhadap eksplorasi karir siswa adalah prestasi akademik. Prestasi akademik yang tinggi memungkinkan siswa dengan mudah melakukan eksplorasi karir karena didukung oleh kemampuan dalam mencerna dan mengolah informasi karir, baik yang diperoleh dari dalam diri maupun dari lingkungan tempat anak tinggal. Pemicu eksternal dalam eksplorasi karir di antaranya adalah tuntutan keluarga untuk berubah, faktor lain yang terkait dengan kehidupan karir, dan tuntutan sosial budaya tempat individu berada. Oran tua merupakan prediktor penting dari eksplorasi karir. Orang tua merupakan individu yang mampu memberi dukungan sosial dan sumber daya psikologis. Orang tua menumbuhkan efek positif pada pengalaman pelaku eksplorasi anak. Menurut Gati dan saka (dalam Gladding, 2012: 417) terkait dengan kesulitan dalam membuat keputusan untuk menentukan karir seseorang banyak orang yang mempunyai kesulitan dalam membuat keputusan karir. Kesulitan ini 
berhubungan dengan tiga factor, baik sebelum maupun selama proses pengambilan keputusan. Faktor-faktor tersebut adalah kurang kesiapan, kurang informasi, dan informasi yang tidak konsisten.

Menurut Gladding (2012: 412) Eksplorasi karir mempunyai sub tahapan yaitu tentatif (usia 14-17), transisi (usia 18-21), dan percobaan (usia 21-24). Tahap-tahap eksplorasi karir seperti yang diuraikan di atas merupakan tahap-tahap yang harus dicapai oleh siswa sesuai dengan tahap perkembangan usia siswa. Tahap perkembangan karir yang harus dicapai lebih dulu pada usia remaja awal ketika masa SMP yaitu fase tentatif pada eksplorasi karir. Tahap-tahap tersebut akan tercapai jika siswa memiliki pengetahuan yang mendasar mengenai karir, di antaranya yaitu informasi jurusan di SMA, M,A dan SMK, serta jenis-jenis pekerjaan.

Jurusan merupakan suatu tempat untuk seorang pelajar yang tempat tersebut disesuaikan dengan bakat, minat, dan kemampuannya, sehingga dalam hal ini penjurusan sangat penting atau besar dampaknya bagi masa depan seseorang. Terdapat tiga jurusan yang dikenal oleh siswa di SMA yaiu jurusa IPA, IPS, dan IPB, sedangkan di SMK terdapat beberapa jurusan yang dikenal oleh siswa. Jurusan tersebut antara lain multimedia, teknik gambar bangunan/ arsitektur, teknik bangunan, teknik permesinan, serta teknik komputer dan jaringan.

Menurut Roe (Winkel dan Hastuti 2006: 630) menggolongkan seluruh jabatan atas dua kategori dasar yaitu jabatan yang berorientasi pada kontak dengan orang lain (person oriented) dan yang berorientasi pada benda-benda (non-person oriented). Contoh bidang jabatan yang tergolong dalam kelompok yang pertama adalah jasa, bisnis, manajemen, pelayanan sosial, dan aktivitas di bidang kultural. Contoh bidang jabatan yang tergolong dalam kelompok yang kedua adalah teknologi, bekerja di lapangan seperti pertanian dan pertambangan, serta penelitian ilmiah. Selanjutnya Holland (Gladding, 2012: 409) mengemukakan bahwa terdapat enam kategori klasifikasi tipe kepribadian dan lingkungan pekerjaan yaitu realistis, investigative, artistik, sosial, enterprising (berani berusaha), dan konvensional (RIASEC). Pendapat Roe dan Holland tersebut, dapat dimaknai bahwa pada dasarnya individu berada pada salah satu kategori yang diungkapkan oleh Roe dan Holland.

\section{Bimbingan Kelompok}

Layanan bimbingan dan konseling terdiri dari berbagai macam jenis, salah satunya yaitu layanan bimbingan kelompok. Nurihsan (2009: 23) menjelaskan bahwa bimbingan kelompok merupakan bantuan terhadap individu yang dilaksanakan dalam situasi kelompok. Bimbingan kelompok dapat berupa penyampaian informasi ataupun aktivitas kelompok membahas masalah pendidikan, pekerjaan, pribadi, dan sosial.

Bimbingan kelompok kaitannya dengan pemahaman eksplorasi karir yaitu siswa dalam situasi kelompok memperoleh bantuan berupa kemudahan dalam menyelesaikan permasalahan terkait dengan kurangnya pemahaman eksplorasi karir pada siswa. Dengan layanan bimbingan kelompok, para siswa dapat diajak untuk bersama-sama mengemukakan pendapat tentang sesuatu dan membicarakan topik-topik penting, mengembangkan nilai-nilai, dan mengembangkan langkah-langkah bersama untuk menangani permasalahan yang dibahas dalam kelompok.

Suatu kelompok agar menjadi efektif perlu melalui tahap-tahap tertentu dan setiap tahap mempunyai ciri-ciri tertentu. Masing-masing tahap itu tidak berdiri sendiri melainkan merupakan satu kesatuan yang utuh dengan tahap-tahap yang lain. Menurut pendapat Hartinah (2009: 132) tahap-tahap perkembangan kelompok dalam layanan bimbingan kelompok adalah tahap pembentukan, tahap peralihan, tahap pembahasan, dan tahap pengakhiran.

Menurut Romlah (2006: 87) teknik yang biasa digunakan dalam pelaksanaan bimbingan kelompok yaitu: teknik pemberian informasi (expository techniques), diskusi kelompok, teknik pemecahan masalah (problem-solving techniques), permainan peranan (roleplaying), permainan simulasi (simulation games), karyawisata (field trip), dan teknik penciptaan suasana kekeluargaan (homeroom). Pelaksanaan layanan bimbingan kelompok dengan teknik diskusi kelompok yaitu proses pemberian bantuan secara kelompok dengan cara berdiskusi dalam situasi kelompok secara berkelanjutan dan sistematis yang dilakukan oleh seorang ahli yang telah mendapat latihan khusus untuk itu. Jadi di dalam pelaksanaan bimbingan kelompok dengan 


\section{EKSPLORASI KARIR, BIMBINGAN KELOMPOK DENGAN TEKNIK DISKUSI KELOMPOK}

teknik diskusi kelompok tidak hanya untuk memecahkan masalah, tetapi juga untuk mencerahkan suatu persoalan, serta pengembangan pribadi.

Menurut Romlah (2006: 89) diskusi kelompok adalah percakapan yang sudah direncanakan antara tiga orang atau lebih dengan tujuan untuk memecahkan masalah atau untuk memperjelas suatu persoalan, di bawah pimpinan seorang pemimpin. Pengertian bimbingan kelompok dengan teknik diskusi kelompok adalah pemberian bantuan kepada sekelompok individu dalam rangka memberikan kemudahan dalam menyelesaikan permasalahan kurangnya pemahaman eksplorasi karir pada siswa. Melalui layanan bimbingan kelompok dengan teknik diskusi kelompok, para siswa dapat diajak untuk bersama-sama mengemukakan pendapat tentang sesuatu dan membicarakan topik-topik penting, mengembangkan nilai-nilai, dan mengembangkan langkah-langkah bersama untuk menangani permasalahan yang dibahas dalam situasi kelompok dengan berdiskusi sesama kelompok.

Terdapat tiga langkah dalam melaksanakan layanan bimbingan kelompok dengan teknik diskusi kelompok:

1. Perencanaan

Pada tahap perencanaan fasilitator melaksanakan lima macam hal yaitu merumuskan tujuan diskusi, menentukan jenis diskusi, apakah diskusi kelas, diskusi kelompok-kelompok kecil, atau diskusi panel, melihat pengalaman dan perkembangan siswa, apakah memerlukan pengarahan-pengarahan yang jelas, tugas yang sederhana waktu diskusi yang lebih pendek atau sebaliknya, memperhitungkan waktu yang tersedia untuk kegiatan diskusi, mengemukakan hasil yang diharapkan diri diskusi, misalnya rangkuman, kesimpulan-kesimpulan atau pemecahan masalah.

\section{Pelaksanaan}

Pada tahap pelaksanaan fasilitator memberikan tugas yang harus didiskusikan, waktu yang tersedia untuk mendiskusikan tugas itu, dan memberitahu cara melaporkan tugas, serta menunjuk pengamatan diskusi apabila diperlukan.
3. Penilaian

Pada tahap penilaian fasilitator meminta pengamat melaporkan hasil pengamatannya, memberikan komentar mengenai proses diskusi dan membicarakannya dengan kelompok.

Penggunaan teknik diskusi kelompok dalam layanan bimbingan kelompok mempunyai keuntungan dan kelemahan. Menurut Romlah (2006: 90-91) berikut keuntungan dan kelemahan dalam diskusi kelompok antara lain:

1. Keuntungan

Membuat anggota kelompok lebih aktif karena tiap anggota mendapat kesempatan untuk berbicara dan memberi sumbangan pada kelompok, anggota kelompok dapat saling bertukar pengalaman, pikiran, perasaan dan nilainilai, yang akan membuat persoalan yang dibicarakan jadi lebih jelas, dapat meningkatkan pengertian terhadap diri sendiri dan pengertian terhadap orang lain, memberi kesempatan pada anggota untuk belajar menjadi pemimpin, baik dengan menjadi pemimpin kelompok maupun dengan mengamati perilaku pimpinan kelompok.

2. Kelemahan

Dapat menjadi salah arah apabila pemimpin kelompok tidak melaksanakan fungsi kepemimpinannya dengan baik, ada kemungkinan diskusi dikuasai oleh individu-individu tertentu, sehingga anggota lain kurang mendapat kesempatan berbicara, membutuhkan banyak waktu dan tempat yang agak luas, terutama untuk diskusi-diskusi kelompok kecil, agar masingmasing kelompok tidak terganggu.

\section{Metode Penelitian}

Metode yang digunakan dalam penelitian ini yaitu penelitian tindakan kelas (PTK) yang dilaksanakan dalam dua siklus. Subjek penelitian berjumlah delapan siswa kelas IX E SMP Muhammadiyah 7 Yogyakarta, yang diambil menggunakan purposive sampling. Instrumen pengumpulan data menggunakan angket pemahaman eksplorasi karir dan pedoman observasi. Pemahaman eksplorasi karir siswa dari sebelum dan sesudah diberikan layanan bimbingan kelompok dengan teknik diskusi kelompok dianalisis menggunakan rumus $t$-tets. 


\section{Hasil Penelitian dan Pembahasan}

Hasil penelitian menunjukkan bahwa terdapat perbedaan pada hasil pretest dan posttest pemahaman eksplorasi karir siswa kelas IX SMP Muhammadiyah 7 Yogyakarta. Perbedaan tersebut dimaknai bahwa terdapat peningkatan pemahaman eksplorasi karir pada siswa setelah mendapatkan perlakuan berupa layanan bimbingan kelompok dengan teknik diskusi kelompok. Peningkatan tersebut ditunjukkan berdasarkan rerata skor pretest pemahaman eksplorasi karir siswa sebesar 119,9 dan rerata skor posttest sebesar 155,8. Peningkatan pemahaman eksplorasi karir pada siswa kelas IX E di SMP Muhammadiyah 7 Yogyakarta dapat dilihat pada Tabel 1.

Tabel 1

Deskripsi Skor Pemahaman Eksplorasi Karir

\begin{tabular}{ccccc}
\hline No & Nama & $\begin{array}{c}\text { Skor } \\
\text { sebelum } \\
\text { tindakan } \\
\text { (pretest) }\end{array}$ & $\begin{array}{c}\text { Skor } \\
\text { setelah } \\
\text { tindakan } \\
\text { (posttest) }\end{array}$ & $\begin{array}{c}\text { Gain } \\
\text { Skor } \\
(\mathrm{d})\end{array}$ \\
\hline 1 & CR & 118 & 173 & 55 \\
2 & AG & 125 & 175 & 50 \\
3 & AN & 124 & 162 & 38 \\
4 & IT & 112 & 147 & 35 \\
5 & DM & 123 & 151 & 28 \\
6 & YD & 126 & 149 & 23 \\
7 & AS & 128 & 145 & 17 \\
8 & RD & 103 & 144 & 41 \\
& Total & 959 & 1246 & 287 \\
\multicolumn{7}{c}{ Mean } & 119,9 & 155,8 & 35,9 \\
\hline \multicolumn{7}{c}{} & & & \\
\hline
\end{tabular}

Selain data hasil pretest dan posttest, terdapat pula data hasil observasi yang merupakan data pendukung penelitian. Data pendukung yang diperoleh, bertujuan untuk memperkuat hasil penelitian. Observasi dilaksanakan dengan menggunakan pedoman observasi. Pedoman observasi disusun sebagai instrumen untuk mengamati aktifitas dan respon siswa selama mengikuti layanan bimbingan kelompok dengan teknik diskusi kelompok. Berdasarkan data hasil observasi, diperoleh gambaran bahwa setiap pertemuan terjadi peningkatan kualitas siswa ketika mengikuti layanan bimbingan kelompok dengan teknik diskusi kelompok. Peningkatan tertinggi dicapai pada pertemuan terakhir. Hal ini terjadi karena semakin hari, siswa semakin memahami tata cara dan proses pelaksanaan layanan bimbingan kelompok. Data hasil observasi yang menggambarkan peningkatan kualitas siswa dalam mengikuti layanan bimbingan kelompok dengan teknik diskusi kelompok dapat dilihat pada Tabel 2.

Tabel 2

Skor Hasil Observasi Pelaksanaan Layanan Bimbingan Kelompok dengan Teknik Diskusi Kelompok

\begin{tabular}{|c|c|c|c|c|c|c|c|}
\hline \multirow[t]{2}{*}{ No } & \multirow[t]{2}{*}{ Nama } & \multicolumn{6}{|c|}{ Pertemuan ke } \\
\hline & & 1 & 2 & 3 & 4 & 5 & 6 \\
\hline 1 & CR & 15 & 15 & 16 & 18 & 20 & 22 \\
\hline 2 & $\mathrm{AG}$ & 14 & 16 & 18 & 20 & 21 & 22 \\
\hline 3 & AN & 15 & 18 & 20 & 21 & 22 & 24 \\
\hline 4 & IT & 17 & 18 & 21 & 22 & 24 & 24 \\
\hline 5 & DM & 14 & 16 & 21 & 23 & 24 & 24 \\
\hline 6 & YD & 12 & 14 & 17 & 19 & 21 & 22 \\
\hline 7 & AS & 15 & 17 & 18 & 19 & 19 & 20 \\
\hline 8 & RD & 14 & 16 & 17 & 18 & 20 & 22 \\
\hline \multirow{2}{*}{\multicolumn{2}{|c|}{ Jumlah }} & 11 & 13 & 14 & 16 & 17 & 18 \\
\hline & & 6 & 0 & 8 & 0 & 1 & 0 \\
\hline \multirow{2}{*}{\multicolumn{2}{|c|}{ Mean }} & 14 & 16 & 18 & 20 & 21 & 22 \\
\hline & &, 5 & ,3 &, 5 & ,0 & ,4 &, 5 \\
\hline
\end{tabular}

Capaian peningkatan pemahaman eksplorasi karir siswa diuraikan pula pada setiap siklus. Pada siklus I, diketahui masih terdapat empat siswa dari jumlah total delapan siswa yang mendapat penilaian cukup ketika pelaksanaan layanan bimbingan kelompok dengan teknik diskusi kelompok. Siswa yang berada pada kategori cukup, dimaknai bahwa siswa tersebut cukup antusias dalam mengikuti layanan bimbingan kelompok, siswa cukup menghormati siswa lain dan peneliti ketika sedang berbicara, siswa sesekali mencatat hal yang dianggap penting. Siswa juga cukup tertib dan sopan selama diskusi berlangsung. Selain itu, siswa cukup aktif berinteraksi dengan anggota dan pemimpin kelompok, siswa cukup aktif dalam mengemukakan pendapat, dan siswa cukup mampu bekerjasama dalam memecahkan masalah. Pada siklus II, respon siswa dan situasi dalam kelompok sudah berada pada kategori baik. Siswa antusias dan aktif dalam diskusi, terjalin interaksi dan kerjasama yang baik sehingga permasalahan dalam diskusi dapat terselesaikan. Pemahaman siswa tentang eksplorasi karir pada siklus kedua lebih baik daripada siklus pertama. Capaian peningkatan pemahaman eksplorasi karir 


\section{EKSPLORASI KARIR, BIMBINGAN KELOMPOK DENGAN TEKNIK DISKUSI KELOMPOK}

siswa pada setiap siklus dapat dilihat pada Tabel 3.

Tabel 3

Deskripsi Hasil Observasi Pelaksanaan Layanan Bimbingan Kelompok Dengan Teknik Diskusi Kelompok

\begin{tabular}{ccc}
\hline Subyek & \multicolumn{2}{c}{ Siklus } \\
& I & II \\
\hline CR & Cukup & Baik \\
AG & Cukup & Baik \\
AN & Baik & Baik \\
IT & Baik & Baik \\
DM & Baik & Baik \\
YD & Cukup & Baik \\
AS & Baik & Baik \\
RD & Cukup & Baik \\
\hline
\end{tabular}

Hipotesis yang diajukan pada penelitian ini adalah "Ada peningkatan pemahaman eksplorasi karir pada siswa kelas IX E SMP Muhammadiyah 7 Yogyakarta". Kebenaran hipotesis penelitian, dapat dibuktikan melalui uji t sampel berpasangan (paired t test).

Berdasarkan hasil perhitungan dengan menggunakan program SPSS diperoleh nilai $\mathrm{t}$ hitung 7,812. Selanjutnya, nilai $t$ hitung dibandingkan dengan nilai $\mathrm{t}$ tabel. Hasil perbandingan menunjukkan bahwa nilai t hitung $>\mathrm{t}$ tabel $(7,812>1,895)$ sehingga hasil perbandingan tersebut dapat dimaknai bahwa ada perbedaan yang signifikan antara pemahaman siswa tentang eksplorasi karir sebelum dan setelah diberi layanan bimbingan kelompok dengan teknik diskusi kelompok. Hal ini ditunjukkan dari nilai rata-rata pemahaman eksplorasi karir sebelum dilakukan layanan bimbingan kelompok dengan diskusi kelompok sebesar 119,87 dan meningkat menjadi 155,75 setelah diberi layanan bimbingan kelompok dengan teknik diskusi kelompok.

Berdasarkan pada urian diatas, maka hipotesis nihil (Ho) yang diajukan berbunyi "tidak ada peningkatan pemahaman eksplorasi karir pada siswa kelas IX E SMP Muhammadiyah 7 Yogyakarta" ditolak sedangkan hipotesis alternatif (Ha) yang diajukan "Ada peningkatan pemahaman eksplorasi karir pada siswa kelas IX E SMP Muhammadiyah 7 Yogyakarta" diterima sehingga teruji kebenarannya. Hasil penelitian ini menunjukkan bahwa teknik diskusi dalam bimbingan kelompok dapat dijadikan alternatif bantuan kepada siswa untuk meningkatkan pemahaman eksplorasi karir.

\section{Simpulan}

Berdasarkan hasil penelitian maka dapat disimpulkan ada peningkatan pemahaman eksplorasi karir melalui layanan bimbingan kelompok dengan teknik diskusi kelompok pada siswa kelas IX E SMP Muhammadiyah 7 Yogyakarta. Hasil penelitian ini dapat dijadikan sebagai informasi bagi guru bimbingan dan konseling dalam upaya meningkatkan pemahaman eksplorasi karir siswa melalui layanan bimbingan kelompok dengan memanfaatkan teknik diskusi kelompok.

\section{Referensi}

Gladding, Samuel T. (2012). Konseling Profesi yang Menyeluruh. Jakarta: Indeks

Hartinah, Sitti. (2009). Konsep Dasar Bimbingan Kelompok. Bandung: Refika Aditama.

Hidayat, M Risyal. 2012. Penganggur Muda Indonesia Tertinggi di Asia. (Online), (https://m.tempo.co/read/news/2012/04/11/090 396328/penganggur-muda-indonesia-tertinggidi-asia, diakses 4 April 2014).

Hikmawati, Fenti. (2011). Bimbingan Konseling. Jakarta: Rajawali Pres.

Nurihsan, Achmad Juntika. (2009). Bimbingan \& Konseling dalam Berbagai Latar Kehidupan. Bandung: PT Refika Aditama.

Purwanta, Edi. (2012). Faktor yang Mempengaruhi Eksplorasi Karier Siswa SLTP. Jurnal Cakrawala pendidikan, 31 (2).

Romlah, Tatiek. (2006). Teori dan Praktek Bimbingan Konseling. Malang: Universitas Negeri Malang.

Suherman, Uman. (2010). Konseling Karir Sepanjang Rentang Kehidupan. Sekolah Pasca Sarjana Universitas Pendidikan Indonesia.

Suhesti, Endang Ertianti. (2012). Bagaimana Konselor Sekolah Bersikap. Yogyakarta: Pustaka Pelajar.

Sukardi, Dewa Ketut. (2008). Pengantar Pelaksanaan Program Bimbingan dan Konseling di Sekolah. Jakarta: Rineka Cipta. 


\section{PRIYATNO}

Winkel, WS \& Sri Hastuti. (2006). Bimbingan dan Konseling di Institusi Pendidikan. Yogyakarta: Media Abadi.

Yusuf, Syamsu LN. (2009). Program Bimbingan \& Konseling di Sekolah. Bandung: Rizqi Press. 